University of Nebraska - Lincoln

DigitalCommons@University of Nebraska - Lincoln

2014

\title{
Current levels of suppression of waterhyacinth in Florida USA by classical biological control agents
}

\author{
Philip Tipping \\ USDA-ARS, Philip.tipping@ars.usda.gov \\ Melissa Martin \\ US Fish and Wildlife, ARM Loxahatchee Wildlife Refuge \\ Eileen Pokorny \\ USDA-ARS \\ Kayla Nimmo \\ Dry Tortugas National Park, Key West, FL \\ Danyelle Fitzgerald \\ Nova University \\ See next page for additional authors
}

Follow this and additional works at: https://digitalcommons.unl.edu/usdaarsfacpub

Tipping, Philip; Martin, Melissa; Pokorny, Eileen; Nimmo, Kayla; Fitzgerald, Danyelle; Dray, Allen F. Jr.; and Center, Ted D., "Current levels of suppression of waterhyacinth in Florida USA by classical biological control agents" (2014). Publications from USDA-ARS / UNL Faculty. 1423.

https://digitalcommons.unl.edu/usdaarsfacpub/1423

This Article is brought to you for free and open access by the U.S. Department of Agriculture: Agricultural Research Service, Lincoln, Nebraska at DigitalCommons@University of Nebraska - Lincoln. It has been accepted for inclusion in Publications from USDA-ARS / UNL Faculty by an authorized administrator of DigitalCommons@University of Nebraska - Lincoln. 


\section{Authors}

Philip Tipping, Melissa Martin, Eileen Pokorny, Kayla Nimmo, Danyelle Fitzgerald, Allen F. Dray Jr., and Ted D. Center 


\title{
Current levels of suppression of waterhyacinth in Florida USA by classical biological control agents
}

\author{
Philip W. Tipping a,*, Melissa R. Martin ${ }^{\mathrm{b}}$, Eileen N. Pokorny ${ }^{\mathrm{a}}$, Kayla R. Nimmo ${ }^{\mathrm{c}}$, Danyelle L. Fitzgerald ${ }^{\mathrm{d}}$, \\ F. Allen Dray Jr. ${ }^{\text {a }}$, Ted D. Center ${ }^{a}$ \\ ${ }^{a}$ USDA-ARS, Invasive Plant Management Laboratory, Ft. Lauderdale, FL, USA \\ ${ }^{\mathrm{b}}$ US Fish and Wildlife, ARM Loxahatchee Wildlife Refuge, Delray Beach, FL, USA \\ ' Dry Tortugas National Park, Key West, FL, USA \\ ${ }^{\mathrm{d}}$ Nova University, Ft. Lauderdale, FL, USA
}

\section{H I G H L I G H T S}

- No integration of herbicides and biocontrol for waterhyacinth control in Florida.

- Biocontrol agents markedly reduced biomass and flowering.

- Surface coverage reduction of $16.8 \%$ by biocontrol unacceptable to most managers.

- Additional agents which reduce surface coverage more likely to promote integration.

\section{A R T I C L E I N F O}

Article history:

Received 18 October 2013

Accepted 23 January 2014

Available online 31 January 2014

\section{Keywords:}

Waterhyacinth

Biological control

Herbicides

Integration

Eichhornia crassipes
G R A P H I C A L A B S T R A C T

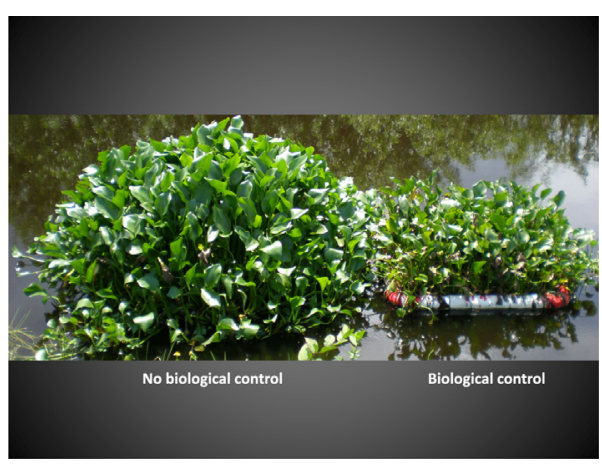

\section{A B S T R A C T}

Waterhyacinth, Eichhornia crassipes (Mart.) Solms (Pontederiaceae), has been a global target for classical biological control efforts for decades. In Florida, herbicidal application is the primary control method employed, usually without regard for the activities of the three biological control agents introduced intentionally during the 1970s, namely Neochetina eichhorniae Warner, Neochetina bruchi, Hustache (Coleoptera: Curculionidae), and Niphograpta albiguttalis Warren (Lepidoptera: Crambidae). A series of field experiments from 2008 to 2010 was conducted at four Florida sites using an insecticide-check approach to quantify the current levels of suppression provided by these agents. In the field N. albiguttalis was rarely found while more than $99 \%$ of all Neochetina sp. adults were $N$. eichhorniae. Although it was not possible to disentangle the relative impacts of Neochetina sp. adults from larvae on individual plant variables, the larvae played a major role in reducing plant biomass and the number of inflorescences. Plots exposed to unrestricted herbivory contained $58.2 \%$ less biomass and produced $97.3 \%$ fewer inflorescences at the end of the experiments. Despite these large reductions, herbivory decreased waterhyacinth coverage by only $16.8 \%$ and most of this was attributed to a low-nutrient site where coverage was reduced disproportionately. Overall, coverage trended upwards during the course of the experiments and was always close to $100 \%$ when the plots were harvested. Although coverage is a somewhat arbitrary metric, especially for floating plants subject to compression and dispersion, it influences the perception of biological control efficacy which, in turn, directly influences herbicide management decisions in Florida. Despite waterhyacinth populations that now produce less than half as much biomass and up to $98 \%$ fewer seeds than before the deployment of biological control agents, the overall approach used to achieve

\footnotetext{
* Corresponding author. Address: USDA-ARS, Invasive Plant Research Laboratory, 3225 College Ave., Ft. Lauderdale, FL 33314 , USA. Fax: +1 9544769169.

E-mail address: philip.tipping@ars.usda.gov (P.W. Tipping).
} 
maintenance control of the plant in Florida will probably not change unless new biological control agents, such as Megamelus scutellaris Berg (Hemiptera: Delphacidae), can reduce coverage significantly.

Published by Elsevier Inc.

\section{Introduction}

Waterhyacinth, Eichhornia crassipes (Mart.) Solms, remains one of the world's worst aquatic weeds despite an array of chemical, mechanical, and biological management options (Holm et al., 1977). In Florida, herbicides remain the control option of choice because of their efficacy, relatively low cost, and consistent support by public funding. In the fiscal year 2012, federal and state programs in Florida spent about \$3.4 million to control the floating macrophytes E. crassipes and waterlettuce, Pistia stratiotes L. (Araceae), on more than 11,000 ha (FWCC, 2012). Managers typically employ maintenance control, a term loosely defined as 'techniques that are used in a coordinated manner, on a continuous or periodic basis, in order to maintain the target plant population at the lowest feasible level as permitted by the availability of funding and technology' (FWCC, 2013). The 2008 economic downturn reduced public funding in Florida for weed control efforts which, in some cases, allowed infestations to rebound and expand, thereby highlighting the crucial linkage between the sustainability of budgets and weed maintenance control programs.

Classical biological control agents, including those developed for $E$. crassipes, are not susceptible to such economic fluctuations; ideally after its release and establishment, an agent propagates and disperses of its own accord, finds the targeted weed and attacks it without further inputs (McFadyen, 1998). Developing these agents can be expensive initially and, because they rarely completely control the target weed, traditional methods are often still required, albeit to a lesser degree (Müller-Scharer and Schäffner, 2008). Despite these facts, biological control is often ignored by some land managers as an asset for cutting costs, in part because of the difficulty or lack of information on integrating biological control into existing management programs. This is typified in Florida where, despite the widespread presence of damaging insect biological control agents on E. crassipes, there is no intentional integration with herbicides because many managers find it easier and simpler to follow routine and regular spray programs against aquatic weed populations (Center et al., 1999). Integrated control is technically feasible against $E$. crassipes as demonstrated by Haag et al. (1988) and Haag and Habeck (1991) who designed and evaluated an integrated approach for $E$. crassipes using herbicides and biological control. A significant commercial industry exists in Florida for applying herbicides to aquatic plants and this may complicate efforts to promote integration with biological control agents because of perceived concerns about the potential loss of revenue if spraying is reduced as part of an integrated program. Most of these contractors are hired by public agencies that provide standard operating practices and routinely supervise and evaluate their results. In an era of general belt-tightening, this may be an opportune time to re-explore practical methods of integrating biological control with herbicidal control in order to reduce overall costs.

Classical biological control projects in Florida developed three insects, namely Neochetina eichhorniae Warner (Coleoptera: Curculionidae), Neochetina bruchi Hustache (Coleoptera: Curculionidae), and Niphograpta albiguttalis (Warren) (Lepidoptera: Crambidae), which were released against waterhyacinth in 1972, 1974, and 1977, respectively (Perkins, 1973; Center et al., 2002). In addition, the gallery-forming mite Orthogalumna terebrantis Wallwork (Acarina: Galumnidae) was accidentally introduced and is also widespread (Cordo and DeLoach, 1976). Samea multiplicalis (Guenée)
(Lepidoptera: Crambidae) and Synclita obliteratis (Walker) (Lepidoptera: Crambidae) are two abundant generalist herbivores whose host range includes E. crassipes (Knopf and Habeck, 1976; Habeck et al., 1986). Evaluation studies have focused primarily on $N$. eichhorniae and $N$. bruchi using before and after release field studies with no- or non-persistent controls, or caged-tank studies with controls (Center and Durden, 1986; Center et al., 1999). It is difficult to maintain controls under field conditions because of agent dispersal and the presence of considerable biotic and abiotic environmental variation among sites. Recently, there has been a renewal of biological control programs in the USA that target $E$. crassipes which makes the evaluation of new agents problematic because of the presence of the existing agents. For example, and although observations of this insect are not presented here, a new agent, Megamelus scutellaris Berg (Hemiptera: Delphacidae), has been developed and was released in Florida in 2010 with the goal of increasing the suppression on the weed (Tipping et al., 2011). Conducting realistic field evaluations of the current agents would provide insight into the performance of newly released agents by disentangling their impacts from their successors.

Thus, the objective of the present studies conducted from 20082010 was to quantify the current level of suppression in the field in Florida provided by previously established agents and to provide a practical assessment of the degree to which these biological control agents are contributing, in aggregate, to the suppression of waterhyacinth in the field.

\section{Materials and methods}

Experiments were conducted over various intervals from 1 to 3 years in lakes, ponds, and canals with varying levels of nutrient availability at sites from north-central Florida to south Florida (Table 1). A randomized complete block design was used with 2 treatments and 4 replications (blocks). The treatments were: (1) an insecticide control where regular applications (acephate $0.07 \%$ ai or bifenthrin $0.01 \%$ ai) were applied until runoff; and (2) a herbivore treatment where only water was applied in the same manner. Neither of the insecticides used inhibited or promoted $E$. crassipes growth in experimental tanks and both were equally effective against herbivores attacking $E$. crassipes. Eight floating frames (made from polyvinyl chloride tubes, $7.6 \mathrm{~cm}$ in diameter) which enclosed 1 square meter were placed at each site, anchored with a rope and cinderblock, and assigned to a treatment. Plastic mesh bags were attached to the underside of each frame to enclose the area to a depth of $1 \mathrm{~m}$ in order to prevent plants from washing out from under the frames.

Experimental plant populations were initiated with five similarly- sized E. crassipes plants from greenhouse colonies that were free of herbivores. The fresh weight biomass of each starting population was recorded and converted to dry weight (DW) biomass by assuming a live plant moisture content of $96 \%$. The experimental plant populations were evaluated every 4-6 weeks for percent coverage (to the nearest 10\%) within the frame using mean visual estimates by two observers. Five plants were chosen without bias from the center of the square, carefully removed, and the following data were recorded: the number of leaves damaged by feeding from Neochetina adults, an estimate of the percentage of the adaxial leaf surfaces of the youngest and oldest leaves that were removed by Neochetina adults ('defoliation') (mean of two 
Table 1

Sites, locations, dates, duration, and nutrient status for field evaluation studies on the suppression of E. crassipes in Florida.

\begin{tabular}{|c|c|c|c|c|c|}
\hline \multirow[t]{2}{*}{ Site } & \multirow[t]{2}{*}{ Location } & \multirow[t]{2}{*}{ Time period } & \multirow[t]{2}{*}{ Duration (d) } & \multicolumn{2}{|c|}{ Mean $( \pm S E)$ tissue $N$ (\% dry weight) } \\
\hline & & & & Control & Herbivory \\
\hline Lake Alice & $\begin{array}{l}29^{\circ} 38^{\prime} 33.24^{\prime \prime} \mathrm{N} \\
82^{\circ} 21^{\prime} 37.74^{\prime \prime} \mathrm{W}\end{array}$ & June $08-$ Nov 08 & 147 & $4.01 \pm 0.15$ & $3.47 \pm 0.39$ \\
\hline Pond 1 & $\begin{array}{l}26^{\circ} 04^{\prime} 56.80^{\prime \prime} \mathrm{N} \\
80^{\circ} 14^{\prime} 32.16^{\prime \prime} \mathrm{W}\end{array}$ & July 08-Feb. 09 & 182 & $1.00 \pm 0.02$ & $0.94 \pm 0.03$ \\
\hline STA1-West & $\begin{array}{ll}26^{\circ} 39^{\prime} & 23.69^{\prime \prime} \mathrm{N} \\
80^{\circ} 24^{\prime} & 03.91^{\prime \prime} \mathrm{W}\end{array}$ & $\begin{array}{l}\text { June } 08-N o v .08 \\
\text { June } 09-N o v .09\end{array}$ & $\begin{array}{l}160 \\
154\end{array}$ & $\begin{array}{l}4.45 \pm 0.22 \\
4.70 \pm 0.27\end{array}$ & $\begin{array}{l}3.64 \pm 0.12 \\
3.81 \pm 0.30\end{array}$ \\
\hline & & May $10-$ Nov. 10 & 184 & $3.35 \pm 0.18$ & $2.62 \pm 0.08$ \\
\hline Edgefield & $\begin{array}{l}29^{\circ} 41^{\prime} 41.12^{\prime \prime} \mathrm{N} \\
81^{\circ} 34^{\prime} 11.89^{\prime \prime} \mathrm{W}\end{array}$ & May 10-Dec. 10 & 196 & $2.17 \pm 0.10$ & $1.51 \pm 0.09$ \\
\hline
\end{tabular}

observers to the nearest $10 \%$ ), the presence or absence of $N$. albittatus, the number of ramets, the number of inflorescences, and the fresh weight biomass of individual plants. Plants were then placed back into the frame at their original locations.

Sampling was modified when coverage exceeded $50 \%$ whereby the five sample plants removed and evaluated were not replaced in the square but instead were broken apart by hand and placed in Berlese funnels to extract herbivores, which were identified and recorded. The youngest plant leaf was removed, dried, ground to a fine powder, and analyzed for \% $\mathrm{N}$ using a $\mathrm{CHN}$ analyzer. These data provided information on the nutrient availability present at each site (Gossett and Norris, 1971). Plant debris was then dried to a constant weight to determine DW biomass. At the end of a specific experiment, all the plant material inside the frames was harvested, dried to a constant weight, and processed to determine DW biomass.

Data were tested for normality and homogeneity of variance and transformed as needed prior to analysis. The influence of herbivory and nutrient availability on plant parameters was examined using repeated measures of ANOVA, regression, and correlation (SAS Institute, 2004). Stepwise forward regression analysis was employed to identify the best predictor variables for E. crassipes coverage, the number of inflorescences, plant density, and area biomass (SAS Institute, 2004). The significance level for entry into the models was 0.50 .

\section{Results}

$N$. albiguttalis was rarely found and more than $99 \%$ of all the Neochetina adults were $N$. eichhorniae. The percent coverage of $E$. crassipes was influenced primarily by the site, much less by the treatment, but with a site $x$ treatment interaction (Table 2) that was caused by a change in magnitude in coverage between treatments at the Pond 1 site, which was much greater than occurred between treatments at the other sites (Table 3 ). The number of inflorescences was affected primarily by site and treatment, with a minor effect from the year (Table 2 ). There was a relatively large site $\times$ treatment interaction that was caused by a change in magnitude between sites like Pond 1 and Lake Alice that had fewer inflorescences, with sites like Edgefield and STA1-West that had greater numbers of inflorescences (Table 3 ). Also, there was a relatively minor year $\mathrm{x}$ treatment interaction (Table 2 ) caused by a change in magnitude whereby the number of inflorescences were greater in 2010 versus earlier years (Table 3). Both plant density and the number of ramets were influenced only by the site (Table 2). The percent damaged leaves and percent defoliation were influenced primarily by the treatment with some minor influences from the site, as well as interactions between the two factors (Table 2) that were caused by a change in magnitude between sites like Edgefield and Lake Alice (or Pond 1) for percent damaged leaves, and STA1-West and Pond1 for percent defoliation (data not shown). Specifically, the means for the percentage of damaged leaves was higher at Edgefield than at either Lake Alice or Pond 1, while the means for percent defoliation were higher at STA1-West than at Pond 1.

The final plant biomass was influenced by all factors including site $\mathrm{x}$ treatment and year $\mathrm{x}$ treatment interactions (Table 2). The most influential factors were the site and treatment with both interactions almost equal (Table 2). The interactions were the result of changes in magnitude to the response of the treatments within both sites and years (Table 3 ). This is reflective of the differences in the means of biomass variables that, while remaining consistent in rank between treatments (i.e. unrestricted herbivory by the biological control agents always suppressed biomass production), varied widely among sites and even within sites over years (Table 3 ). While 0 . terebanthis or $N$. eichhorniae adults were not affected by any factor, Neochetina larvae were influenced by the treatment (Table 2).

Table 2

Results of ANOVA for plant and insect variables with site, year, and treatment as main factors.

\begin{tabular}{|c|c|c|c|c|c|c|c|c|c|c|}
\hline \multirow[t]{2}{*}{ Variables } & \multicolumn{2}{|c|}{ Site $(S)$} & \multicolumn{2}{|c|}{ Year $(\mathrm{Y})$} & \multicolumn{2}{|c|}{ Treatment $(\mathrm{T})$} & \multicolumn{2}{|c|}{$\mathrm{S} \times \mathrm{T}$} & \multicolumn{2}{|c|}{$\mathrm{Y} \times \mathrm{T}$} \\
\hline & df & TSS (\%) & df & TSS (\%) & df & TSS (\%) & df & TSS (\%) & df & TSS (\%) \\
\hline$\%$ Cover & 3 & $36.6^{* *}$ & 2 & 0.2 & 1 & $2.3^{* *}$ & 3 & $4.1^{* *}$ & 2 & 0.2 \\
\hline \# Inflorescences & 3 & $29.0^{* *}$ & 2 & $7.3^{* *}$ & 1 & $17.5^{* *}$ & 3 & $25.6^{* *}$ & 2 & $7.6^{* *}$ \\
\hline Density & 3 & $11.4^{*}$ & 2 & 1.7 & 1 & 0.001 & 3 & 9.0 & 2 & 1.1 \\
\hline \# Ramets & 3 & $34.0^{* *}$ & 2 & 1.7 & 1 & 2.9 & 3 & 3.3 & 2 & 1.3 \\
\hline Damaged leaves\% & 3 & $11.3^{* *}$ & 2 & $2.1^{*}$ & 1 & $46.3^{* *}$ & 3 & $8.7^{* *}$ & 2 & 1.1 \\
\hline \% Defoliation & 3 & $6.4^{* *}$ & 2 & 2.5 & 1 & $36.5^{* *}$ & 3 & $17.3^{* *}$ & 2 & 3.1 \\
\hline Biomass ( $\mathrm{g} \mathrm{DW} \mathrm{m}^{-2}$ ) & 3 & $25.8^{* *}$ & 2 & $1.6^{*}$ & 1 & $18.1^{* *}$ & 3 & $10.3^{* *}$ & 2 & $9.4^{* *}$ \\
\hline \# Neochetina adults & 3 & 5.0 & 2 & 1.8 & 1 & 3.0 & 3 & 6.5 & 2 & 4.6 \\
\hline \# Neochetina larvae & 3 & 6.1 & 2 & 0.8 & 1 & $15.7^{* *}$ & 3 & 5.6 & 2 & 1.5 \\
\hline \# Orthogalumna mites & 3 & 0.8 & 2 & 9.3 & 1 & 6.3 & 3 & 0.8 & 2 & 9.3 \\
\hline
\end{tabular}

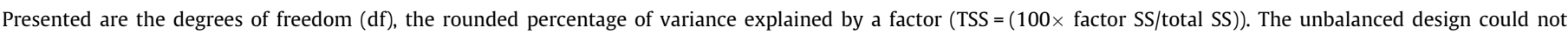
interpret the $\mathrm{S} \times \mathrm{Y}$ and $\mathrm{S} \times \mathrm{Y} \times \mathrm{T}$ interactions.

${ }^{*} p=0.05$

$p=0.01$ 
Table 3

Means $( \pm \mathrm{SE})$ of variables for different sites and years for all sample dates.

\begin{tabular}{|c|c|c|c|c|c|c|c|c|c|}
\hline Site & Year & $\operatorname{Trt}^{\mathrm{a}}$ & $\begin{array}{l}\text { Surface } \\
\text { coverage (\%) }\end{array}$ & $\begin{array}{l}\text { Infloresences } \\
\left(\# \mathrm{~m}^{-2}\right)\end{array}$ & $\begin{array}{l}\text { Plant density } \\
\left(\# \mathrm{~m}^{-2}\right)\end{array}$ & $\begin{array}{l}\text { Plant biomass } \\
\left(\mathrm{g} \mathrm{DW} \mathrm{plant}^{-1}\right)\end{array}$ & $\begin{array}{l}\text { Area biomass } \\
\left(\mathrm{Kg} \mathrm{DW} \mathrm{m}^{-2}\right)\end{array}$ & $\begin{array}{l}\text { Neochetina adults } \\
\text { (\# plant }^{-1} \text { ) }\end{array}$ & $\begin{array}{l}\text { Neochetina larvae } \\
\text { (\# plant }^{-1} \text { ) }\end{array}$ \\
\hline \multirow[t]{2}{*}{ Lake Alice } & 2008 & $\mathrm{C}$ & $37.6 \pm 5.6$ & $3.7 \pm 1.3^{*}$ & $23.8 \pm 7.5$ & $11.5 \pm 2.7^{* *}$ & $3.1 \pm 0.1^{* *}$ & $0.0 \pm 0.0$ & $0.0 \pm 0.0$ \\
\hline & & $\mathrm{H}$ & $42.4 \pm 5.6$ & $0.7 \pm 1.3$ & $34.7 \pm 10.4$ & $6.8 \pm 0.7$ & $1.4 \pm 0.1$ & $0.02 \pm 0.01$ & $0.2 \pm 0.1$ \\
\hline \multirow[t]{2}{*}{ Edgefield } & 2010 & $\mathrm{C}$ & $67.3 \pm 7.3$ & $6.7 \pm 2.4$ & $96.9 \pm 40.4$ & $13.2 \pm 1.2$ & $2.9 \pm 0.2^{* *}$ & $0.01 \pm 0.01^{* *}$ & $0.0 \pm 0.0^{* *}$ \\
\hline & & $\mathrm{H}$ & $63.2 \pm 7.2$ & $3.1 \pm 1.2$ & $110.9 \pm 48.1$ & $9.6 \pm 0.8$ & $1.5 \pm 0.2$ & $0.2 \pm 0.04$ & $0.9 \pm 0.2$ \\
\hline \multirow[t]{2}{*}{ Pond 1} & 2008 & $\mathrm{C}$ & $60.0 \pm 5.2^{* *}$ & $2.3 \pm 0.6^{* *}$ & $77.1 \pm 11.2^{* * *}$ & - & $0.9 \pm 0.3$ & $0.05 \pm 0.05$ & $0.0 \pm 0.0$ \\
\hline & & $\mathrm{H}$ & $28.1 \pm 4.2$ & $0.1 \pm 0.07$ & $37.6 \pm 6.1$ & - & $0.3 \pm 0.2$ & $0.3 \pm 0.05^{*}$ & $1.5 \pm 0.9$ \\
\hline \multirow[t]{6}{*}{ STA1-West } & 2008 & $\mathrm{C}$ & $63.0 \pm 8.3$ & $5.3 \pm 1.6$ & $74.2 \pm 20.3$ & $16.2 \pm 3.1^{* *}$ & $1.3 \pm 0.7$ & $0.0 \pm 0.0$ & $0.0 \pm 0.0^{* *}$ \\
\hline & & $\mathrm{H}$ & $64.8 \pm 6.9$ & $0.1 \pm 0.06$ & $76.1 \pm 15.7$ & $7.1 \pm 0.7$ & $0.4 \pm 0.1$ & $0.4 \pm 0.2$ & $2.2 \pm 0.5$ \\
\hline & 2009 & $\mathrm{C}$ & $84.4 \pm 5.2$ & $5.0 \pm 1.5^{*}$ & $39.3 \pm 13.6$ & $26.7 \pm 4.6^{* *}$ & $1.9 \pm 0.7$ & $0.05 \pm 0.03$ & $0.06 \pm 0.02^{* *}$ \\
\hline & & $\mathrm{H}$ & $88.5 \pm 4.5$ & $1.2 \pm 0.4$ & $61.6 \pm 29.7$ & $10.6 \pm 1.0$ & $0.7 \pm 0.2$ & $0.2 \pm 0.05$ & $1.8 \pm 0.2$ \\
\hline & 2010 & $\mathrm{C}$ & $89.6 \pm 4.7$ & $8.4 \pm 1.5^{* * *}$ & $43.2 \pm 18.2$ & $22.5 \pm 3.8^{*}$ & $2.6 \pm 0.6$ & $0.1 \pm 0.05$ & $0.2 \pm 0.1^{* *}$ \\
\hline & & $\mathrm{H}$ & $87.8 \pm 4.6$ & $3.1 \pm 0.9$ & $48.0 \pm 17.8$ & $15.2 \pm 1.2$ & $1.9 \pm 0.2$ & $0.2 \pm 0.07$ & $2.1 \pm 0.4$ \\
\hline
\end{tabular}

a Trt $=$ experimental treatment where $\mathrm{C}$ was the insecticide control and $\mathrm{H}$ was unrestricted herbivory by biological control agents.

$t=0.05$ and 0.01 , respectively, when comparing means between treatments within variables, sites, and years.

Waterhyacinth plots with greater coverage contained more plants $(r=0.83, n=132, P<0.0001)$, greater biomass $(r=0.35$, $n=216, P<0.0001)$, and produced more inflorescences $(r=0.32$, $n=379, P<0.0001)$. The density of $N$. eichhorniae adults influenced the percentage of damaged leaves $(r=0.23, n=161, P=0.002)$ and percent defoliation $(r=0.29, n=161, P=0.0002)$, while the density of larvae influenced the number of inflorescences $(r=-0.27$, $n=157, P=0.0006)$ and individual plant biomass $(r=-0.22$, $n=162, P=0.004)$. Although it was not possible to completely disentangle the relative impacts of each life stage on individual plant variables, it appeared that the feeding and boring activities of the larvae played a predominant role in reducing plant biomass and the number of inflorescences. This was evident from regression models that consistently identified Neochetina larvae as one of the most important components in E. crassipes coverage, the number of inflorescences, density, and biomass (Table 4). Nutrient availability (\% $\mathrm{N}$ ) was also a significant component that accounted for the variation in the plant response variables (Table 4).

\section{Discussion}

Biological control agents have been deployed in the field in Florida against waterhyacinth since 1972 (Perkins, 1974) and are markedly suppressing the growth and reproduction of this weed. Plots with unrestricted herbivory contained $58.2 \%$ less plant biomass and $97.3 \%$ fewer inflorescences. Despite these large reductions, coverage was relatively unaffected averaging $71.1 \pm 7.8 \%$ in plots with biological control compared with $85.5 \pm 5.6 \%$ in plots

Table 4

Stepwise forward regression of $E$. crassipes across all sites with independent abiotic and biotic variables.

\begin{tabular}{llllll}
\hline Dependent & Step & Independent variable & $r^{2}$ & $p$ & Slope \\
\hline Coverage & 1 & Neochetina larvae & 0.48 & 0.002 & -1.43 \\
& 2 & \% N & 0.50 & 0.46 & -1.66 \\
Inflorescences & 1 & \% N & 0.35 & 0.01 & 7.21 \\
& 2 & Neochetina larvae & 0.42 & 0.19 & -1.06 \\
Density & 1 & Neochetina larvae & 0.22 & 0.05 & -6.20 \\
& 2 & N. eichhornia adults & 0.30 & 0.22 & -109.80 \\
& 3 & S. obliteralis larvae & 0.42 & 0.12 & 56.87 \\
Area biomass & 1 & \% N & 0.48 & 0.24 & -21.89 \\
& 2 & \% N N & 0.35 & 0.01 & -2.27 \\
& 2 & 0.43 & 0.19 & 9.73 \\
\hline
\end{tabular}

List of independent variables entered to select from: number of Neochetina larvae, Neochetina adults, $O$. terebanthis, S. obliteralis larvae, and S. mulitplicalis larvae per plant, and \% $\mathrm{N}$ in E. crassipes tissue. Presented are the explained cumulative variance $\left(r^{2}\right)$, the level of significance of each added variable, and the slope. without, a decrease of $16.8 \%$. However, most of this difference was attributed to the low-nutrient Pond 1 site which was the only site where coverage was reduced by biological control. Overall, in spite of the other effects of biological control, coverage always trended upwards over the course of the experiments and was always close to $100 \%$ when the plots were harvested.

Although coverage is a somewhat arbitrary measure, it disproportionately influences perceptions of the efficacy of biological control in Florida which, in turn, directly influences management decisions. For example, a floating mat of waterhyacinth that covers the same area but weighs half as much and produces up to $98 \%$ fewer seeds should provide compelling incentives to explore new management strategies. However, there is scant evidence of this as aquatic resource managers often focus solely on reducing coverage as their management goal, a premise seemingly based on the maximization of open water, a task accomplished through the repeated and perpetual application of herbicides through maintenance control schedules that are designed to keep plant populations relatively small. The benefits of this approach include an overall reduction in the amount of herbicide used, less sedimentation, and greater access to waterways. However, as long as coverage remains the sole metric for decision-making, the current and significant levels of biological control that have been achieved will continue to be perceived as insufficient and ineffective.

Center and Dray (2010) argued that predictable and consistent results such as those achieved with herbicides should not be expected of biological control because feeding by Neochetina reduces plant quality, which in turn eventually inhibits their reproduction, thereby ultimately limiting the herbivory pressure from successive generations of biological control agents. In this study, coverage was significantly influenced by the site indicating the influence of the environment on biological control efficacy. Heard and Winterton (2000) interpreted their tank studies to mean that controlling $E$. crassipes through biological control will be easier at lower nutrient conditions because plant biomass accumulation will be lower. Center et al. (2005) also suggested that E. crassipes would be less likely to persist in lower nutrient environments when exposed to herbivory by Neochetina weevils. The field results from lownutrient Pond 1 site appear to corroborate these interpretations: coverage, flowering, and density were all reduced by herbivory, but only flowering was consistently reduced at the other, more eutrophic sites. Despite the differences in nutrient availability, the densities of Neochetina life stages were not different among sites which may indicate that these insects have reached their maximum effectiveness as classical biological control agents in the current management of E. crassipes in Florida. 
Further studies on the current and future herbivore impacts on the susceptibility of $E$. crassipes to herbicides and the speed at which plant populations rebound following herbicide treatment may reveal additional benefits and provide guidance toward a more nuanced integration of herbicide and biological controls. For example, Center and Dray (2010) suggested a more judicious pattern of herbicide use designed to create both higher quality plants and unsprayed refuges for the insects as was demonstrated by Haag et al. (1988). Although these data indicated that herbivory did reduce coverage during the growing season, coverage generally increased over the duration of the studies, except at the lower nutrient availability Pond 1 site, to levels that would be considered as unacceptable to most managers in Florida. Whether or not the addition of $M$. scutellaris or other insects will reduce coverage below current levels in Florida remains to be seen.

It should be more widely recognized that herbicide-based maintenance programs owe much of their success to the overall transformation and weakening of the plant by the established biological control agents. However, unless coverage is reduced significantly by biological control, it will probably not change the current approach used to suppress waterhyacinth in Florida.

\section{Acknowledgments}

We thank the South Florida Water Management District, the University of Florida, and the St. Johns River Water Management District for permitting access to field sites on their property.

\section{References}

Center, T.D., Durden, W.C., 1986. Variation in waterhyacinth/weevil interactions resulting from temporal differences in weed control efforts. J. Aquat. Plant Manage. 24, 28-38.

Center, T.D., Dray Jr., F.A., Jubinsky, G.P., Grodowitz, M.J., 1999. Biological control of water hyacinth under conditions of maintenance management: can herbicides and insects be integrated? Environ. Manage. 23, 241-256.
Center, T.D., Hill, M.P., Cordo, H., Julien, M.H., 2002. Waterhyacinth. In: Van Driesche, R., Lyon, S., Blossey, B., Hoddle, H., Reardon, R. (Eds.), Biological Control of Invasive Plants in the Eastern United States, USDA Forest Service FHTET-2002-04, pp. 41-64.

Center, T.D., Van, T.K., Dray Jr., F.A., Franks, S.J., Rebelo, M.T., Pratt, P.D., Rayamajhi, M.B., 2005. Herbivory alters competitive interactions between two invasive aquatic plants. Biol. Control 33, 173-185.

Center, T.D., Dray Jr., F.A., 2010. Bottom-up control of water hyacinth weevil populations: do the plants regulate the insects? J. Appl. Ecol. 47, 329-337.

Cordo, H.A., DeLoach, C.J., 1976. Biology of the waterhyacinth mite in Argentina. Weed Sci. 24, 245-249.

FWCC, 2012. Annual Report of Activities conducted under the cooperative aquatic plant control program in Florida public waters for fiscal year, 2011-2012, p. 22.

FWCC, 2013. Available from: <http://myfwc.com/licence/aquatic-plants/permitsrules>.

Gossett, D.R., Norris, W.E., 1971. Relationship between nutrient availability and content of nitrogen andphosphorous in tissues o the aquatic macrophyte Eichhornia crassipes [Mart.] Solms. Hydrobiologia 38, 15-28.

Haag, K.M., Glenn, M.S., Jordan, J.C., 1988. Selective patterns of herbicide application for improved biological control of waterhyacinth. J. Aquat. Plant Manage. 26, $17-19$.

Haag, K.M., Habeck, D.H., 1991. Enhanced biological control of waterhyacinth following limited herbicide application. J. Aquat. Plant Manage. 29, 24-28.

Habeck, D.H., Haag, K., Buckingham, G., 1986. Native insect enemies of aquatic macrophytes-moths. Aquatics 8, 17-19.

Heard, T.A., Winterton, S.L., 2000. Interactions between nutrient status and weevil herbivory in the biological control of water hyacinth. J. Appl. Ecol. 37, 117-127.

Holm, L.G., Plucknett, D.L., Pancho, J.V., Herberger, J.P., 1977. The World's Worst Weeds: Distribution and Biology. University Press, Honolulu, Hawaii.

Knopf, K.W., Habeck, D.H., 1976. Life history and biology of Samea multiplicalis. Environ. Entomol. 5, 539-542.

McFadyen, R.E.C., 1998. Biological control of weeds. Ann. Rev. Entomol. 43, 369393.

Müller-Scharer, H., Schäffner, U., 2008. Classical biological control: exploiting enemy escape to manage plant invasion. Biol. Invasions 10, 859-874.

Perkins, B.D., 1973. Release in the United States of Neochetina eichhorniae Warner, an enemy of waterhyacinth. In: Proceedings 26th Annual Meeting South, Weed Sci. Soc. Abstract, p. 368.

Perkins, B.D., 1974. Arthropods that stress water hyacinth. Pest Art. News Summaries 20, 304-314.

SAS Institute, 2004. The SAS/STAT 9.1 User's Guide, vol 1-7. SAS Institute, Cary NC, p. 5180.

Tipping, P.W., Center, T.D., Sosa, A.J., Dray Jr., F.A., 2011. Host specificity assessment and potential impact of Megamelus scutellaris (Hemiptera: Delphacidae) on waterhyacinth Eichhornia crassipes (Pontederiales: Pontederiaceae). Biocontrol Sci. Technol. 21, 75-87. 